\title{
Biostratigraphy of the upper Bajocian-middle Callovian (Middle Jurassic), South America
}

\author{
A. C. RicCardi, ${ }^{1}$ G. E. G. Westermann, ${ }^{2}$ and S. Elmi ${ }^{3}$ \\ ${ }^{1}$ CONICET/División Paleozoologia Invertebrados, Museo de Ciencias Naturales, Paseo del Bosque s/n, \\ 1900 La Plata, Argentina; ${ }^{2}$ McMaster University, Hamilton, Ontario, Canada; \\ ${ }^{3}$ Université Claude-Bernard, Lyon 1, France \\ (Received October 1990; accepted May 1991)
}

\begin{abstract}
The biostratigraphic division of the upper Bajocian-middle Callovian of South America is based on ammonites from different sections of the following provinces and regions: Neuquén, Mendoza, and San Juan in Argentina; Malleco, Linares, Talca, Atacama, Antofagasta, and Tarapacá in Chile. The complete upper Bajocian-middle Callovian succession includes the following biostratigraphic units: the Megasphaeroceras magnum assemblage zone, lowermost upper Bajocian; the Cadomites-Tulitidae mixed assemblage, (?lower) middle and upper Bathonian; the Steinmanni zone, index Lilloettia steinmanni (Spath), uppermost Bathonian, with two local horizons - Stehnocephalites gerthi horizon (Argentina) and Choffatia jupiter horizon (northern Chile); the Vergarensis zone, index Eurycephalites vergarensis (Burck.), near the Bathonian-Callovian boundary; the Bodenbenderi zone, index Neuquenicerás (Frickites) bodenbenderi (Tornq.), lower Callovian; the Proximum zone, index Hecticoceras proximum Elmi, uppermost lower Callovian; and the Rehmannia (Loczyceras) patagoniensis horizon, middle Callovian.
\end{abstract}

\begin{abstract}
Resumen-La división bioestratigráfica del Bajociano superior-Caloviano inferior de América del Sur está basada en la fauna de amonites proveniente de diferentes secciones de las provincias/regiones de Neuquén, Mendoza, San Juan (Argentina), Malleco, Linares, Talca, Atacama, Antofagasta, y Tarapacá (Chile). La sucesión del Bajociano superior-Caloviano medio incluye las siguientes unidades bioestratigráficas: zona de asociación de Megasphaeroceras magnum, Bajociano superior bajo; asociación de mezcla de CadomitesTulitidae, Bathoniano (?inferior) medio y superior; zona de Steinmanni, fósil guía Lilloettia steinmanni (Spath), Bathoniano superior alto, con dos horizontes locales - horizonte con Stehnocephalites gerthi (Argentina) y horizonte con Choffatia jupiter (norte de Chile); zona de Vergarensis, fósil gula Eurycephalites vergarensis (Burck.), aproximadamente límite Bathoniano-Caloviano; zona de Bodenbenderi, fósil guia Neuqueniceras (Frickites) bodenbenderi (Tornq.), Caloviano inferior; zona de Proximum, fosil guia Hecticoceras proximum Elmi, Caloviano inferior alto; horizonte con Rehmannia (Loczyceras) patagoniensis, Caloviano medio.
\end{abstract}

\section{INTRODUCTION}

FOR THE LAST 25 years, two of us (ACR and GEGW) have conducted field and laboratory research on the Middle Jurassic of South America. These studies have resulted in a number of publications dealing with Aalenian-Callovian ammonite faunas and biostratigraphic zonation and correlation throughout Argentina, Chile, and Peru. Either ACR or ACR and GEGW have studied most of the sections. Additional information and/or material on these sections has been contributed by G. Chong, C. Cornejo, V. Covacevich, J. Davidson, C. Gulisano, A. Hillebrandt, A. Jensen, J. Muñoz, E. Pérez d'A., L. A. Quinzio, R. Vicencio, and J.-C. Vicente. As a result, a formal zonal succession has been developed for the AalenianCallovian (Westermann and Riccardi, 1979; Riccardi, 1984b) of the region. Additional information on the Aalenian was provided by Hillebrandt and Westermann (1985). All other ammonite stratigraphy described in this region (e.g., Groeber et al., 1953; Stipanicic, 1966, 1969; Hillebrandt, 1970; Bogdanic

Address all correspondence and reprint requests to: Dr. A. C. Riccardi (telephone: [54] (21) 24-4278; telefax: [54] (21) 25-5004). and Chong, 1985) is referred to European standard zones.

The first Bathonian-Callovian zonation (Riccardi, 1984b) was based primarily on Eurycephalitinae distribution in the Chacay Melehue section, Neuquén Province, Argentina. Despite similar ammonites of other areas studied by different authors (Gottsche, 1878; Steinmann, 1881; Tornquist, 1898; Burckhardt, 1900a,b, 1903; Stipanicic, 1966; Cornejo et al., 1982), the rich fauna described by Stehn (1923) from that locality represents the most complete Eurycephalitinae succession of the entire Andes. Analysis of the whole assemblage resulted in the delineation of several assemblages (Riccardi, 1984b), even if restriction of this subfamily to the east Pacific subrealm renders it almost useless for correlation with European standard zones. Evidence provided by relatively rare pandemic representatives of the oppeliids and perisphinctids from Chacay Melehue, supplemented by similar faunas found at Caracoles, Antofagasta, Chile, were subsequently used by Riccardi et al. (1988a,b, 1990) to propose the validity of most of these biostratigraphic units throughout the Andes.

Recently, the Bajocian-Callovian Eurycephalitinae and Reineckeiidae have been revised taxonomically and chronologically (Riccardi and Westermann, 1991a,b) by examining all available speci- 

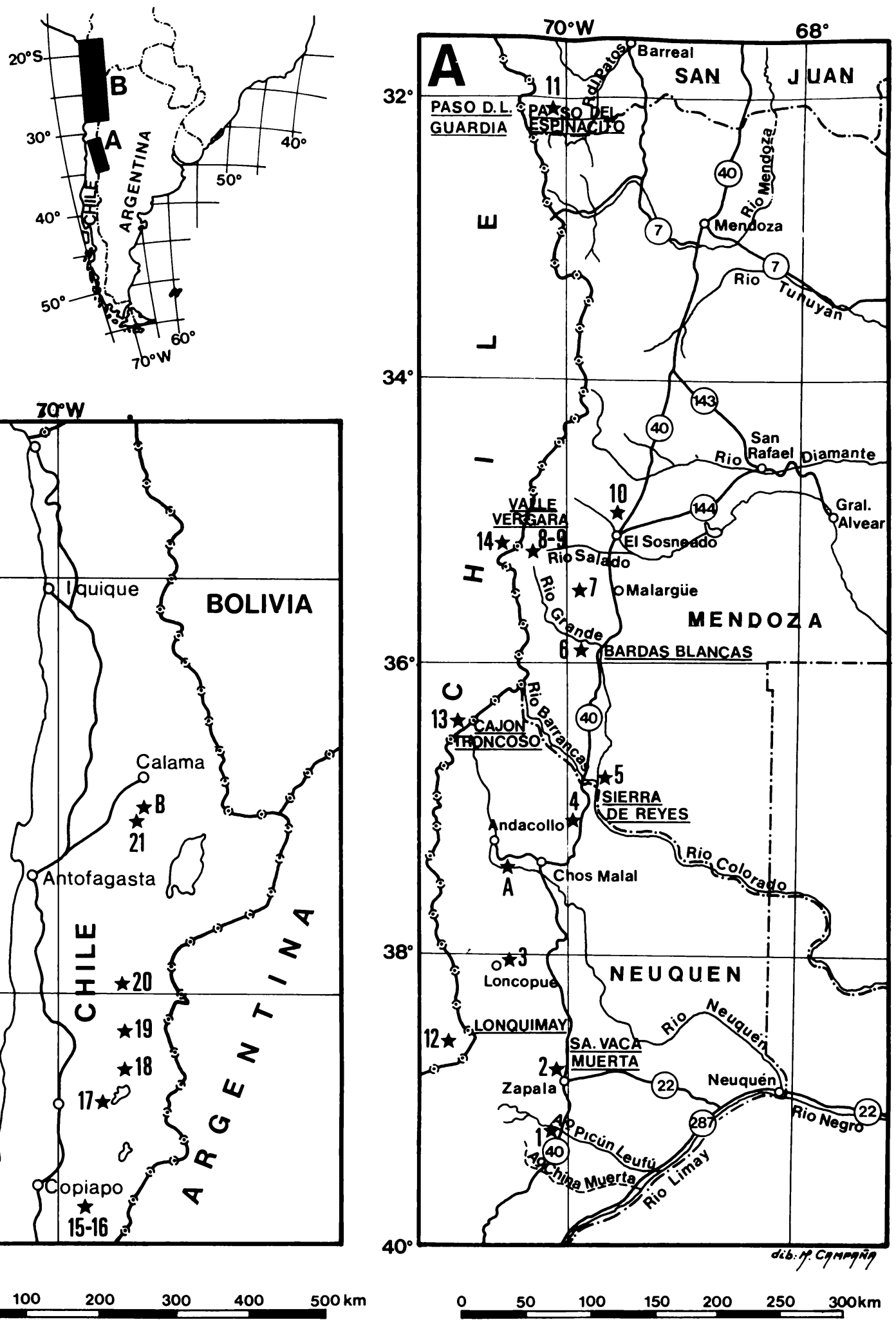

Fig. 1. Index map for the upper Bajocian-middle Callovian ammonoid localities in the Argentine-Chilean Andes. In Argentina, Neuquén province: 1) Picun Leufú, 2) Arroyo Mulichinco, 3) Arroyo Agua Fria, 4) Vega de la Veranada; Mendoza province: 5) Sierra de Reyes (La Estrechura, Quebrada Remoredo, Quebrada de la Buitrera, Aguada de la Mula, Agua del Naco), 6) Arroyo de la Vaina, 7) Cerro Puchenque, 8) Arroyo La Bajada, 9) Cerro de Las Yeseras, 10) Arroyo Blanco; San Juan province: 11) Paso del Espinacito. In Chile, Malleco province, 12) Lonquimay; Linares province, 13) Cajón Troncoso; Talca province, 14) Valle Vergara; Atacama region, 15) Quebrada Calquis, 16) Manflas, 17) Salar de Pedernales, 18) Quebrada de los Burros; Antofagasta province, 19) Quebrada Incahuasi, 20) Quebrada El Profeta, 21 ) Quebrada San Pedro; Tarapacá region, 22) Iquique. 
mens, most types, and many new localities in the provinces/regions of Neuquen, Mendoza, and San Juan in Argentina, and of Malleco, Linares, Talca, Atacama, Antofagasta, and Tarapacá in Chile. These studies support and improve the previous zonal scheme.

Three levels of stratigraphic units are distinguished in classifying the Andean fossiliferous succession based on its ammonites (Riccardi et al., 1990). The lowest level comprises the "faunal horizon," the next level is the "assemblage zone," and the third level of classification is the "standard chronozone."

Fossil specimens shown here are in the collections of the La Plata Museum, Argentina (MLP) and the Geologisch-Paläontologisches Institut, Georg August Universität, Göttingen, Germany (GAUG).

\section{BIOSTRATIGRAPHY}

\section{Key Sections}

Chacay Melehue, Argentina. The Jurassic of the Chacay Melehue area (Fig. 1A) has been described by Keidel (1910), Jaworski (1914, 1925), Groeber (1918), Stehn (1923), Leanza (1945, 1946, 1947), Groeber et al. (1953), Stipanicic (1966), Zöllner and Amos (1973), and Rosenfeld and Volkheimer (1980).

Aalenian-Bajocian biostratigraphy and the Hildocerataceae and Stephanocerataceae of this section have been dealt with by Westermann and Riccardi $(1972,1979)$. More recently, the stratigraphy and ammonoids of the supposed Kimmeridgian beds were studied by Riccardi and Westermann (in Dellape et al., 1979), who reassigned them to the CallovianOxfordian. Lower Jurassic stratigraphy and bivalves have been studied by Damborenea (1987). Upper Bajocian-Callovian stratigraphy and eurycephalitine systematics have been discussed by Westermann (1981), Riccardi (1983, 1984a,b 1985), and Westermann and Riccardi (1985), and have been revised by Riccardi and Westermann (1991a).

The fossiliferous sucession consists of about 1300 1400 meters of marine sediments ranging in age from Pliensbachian to Oxfordian. The upper Bajocianlower Callovian is about 990 meters thick. The Pliensbachian-Callovian succession includes about 30 tuffaceous levels. Samples from these levels collected by ACR, together with S. Damborenea, M. Manceñido, and $\mathrm{S}$. Ballent, are undergoing radiometric analysis.

Caracoles, Chile. Jurassic fossils from Caracoles (Fig. 1B) were discovered over a century ago (Gottsche, 1878); they were systematically described by Steinmann (1881; also Stehn, 1923), but without information on stratigraphy and locality. The stratigraphy was described by Harrington (1961), and the biostratigraphy by Westermann and Riccardi (1979), Riccardi et al. (1988a,b, 1990), and Riccardi and Westermann (1991a,b). The main section examined for this study is south and east of an old cemetery associated with a mine. This excellent outcrop ex- poses about 55-60 meters of upper Bathonian-lower Callovian shales with fossiliferous limestone concretions. Other sections were studied at Quebrada Descubridora, Quebrada Torcazas, and Quebrada Honda.

\section{Additional Sections}

Bajocian-Callovian ammonite stratigraphy and Eurycephalitinae and Reineckeiidae taxonomy have also been studied in the Neuquen, Mendoza, and San Juan provinces in Argentina and in the following provinces/regions in Chile: Malleco, Linares, Talca, Atacama, Antofagasta, and Tarapacá (Fig. 1). These are also described or discussed in Riccardi and Westermann (1991a,b).

\section{AMMONITE ASSEMBLAGES, BIOZONES, AND STANDARD ZONES}

\section{Megasphaeroceras magnum Assemblage Zone}

This zone is introduced for the "(?)Megasphaeroceras rotundum assemblage zone" of Westermann and Riccardi (1979; see also Riccardi and Westermann, 1984; Riccardi, 1984b; Riccardi et al., 1988a,b, 1990). The $M$. rotundum assemblage zone was formally introduced by Hall and Westermann (1980) for North America, and it was tentatively recognized in the Andes by Westermann and Riccardi (1979) on the basis of a fossil assemblage in which they identified Megasphaeroceras aff. rotundum (Imlay). The material has now been ascribed to $M$. magnum by Riccardi and Westerman (1991a,b).

This zone is represented at Chacay Melehue by about 60 meters of sediments with Teloceras crickmayi chacayi West. \& Ricc., Duashnoceras aff. andinense (Hill.), Cadomites n.sp., Megasphaeroceras magnum Ricc. \& West. (Fig. 3, no. 1a-b), Lissoceras cf. oolithicum (Orb.), Oppelia cf. pulchra Buck., Strenoceras or Parastrenoceras sp.juv., Leptosphinctes $(L$. coronarius Buck. n.subsp., and Lobosphinctes intersertus Buck.

A very similar assemblage is present in the Cordillera Domeyko (Quebrada El Profeta, Quebrada San Pedro), northern Chile, with Megasphaeroceras magnum, Teloceras, Cadomites n.sp., and Leptosphinctes, as well as Spiroceras and rare ?Orthogarantiana. A single Strenoceras was found at Caracoles (Westermann and Riccardi, 1980). Below, in the same area, another assemblage occurs (Hillebrandt, 1977), with Lupherites dehmi (Hill.), S. (Stemmatoceras) spp., inflated Stephanoceras ex gr. umblicum (Quenstedt), and Teloceras spp. On the basis of this assemblage, Westermann and Riccardi (1979) introduced the Lupherites dehmi assemblage subzone; it is apparently time equivalent to the Banksii subzone (Riccardi et al., 1990).

The zonal index has also been recorded in Sierra de Reyes (Quebrada Remoredo, ?Quebrada de la Buitrera) and Cerro de las Yeseras, Mendoza province, Argentina; and in Quebrada Calquis and 
Manflas, Atacama province, Chile (Fig. 1, loc. 5, 9, 15-16).

This assemblage supports correlation with the Subfurcatum (Niortense) standard zone, mainly the Baculatum subzone (Fig. 2). The large Lobosphinctes intersertus Buck. found at Chacay Melehue occurs typically in the English Parkinsoni zone. We have therefore assumed that the upper Bajocian at Chacay Melehue is strongly condensed.

\section{Cadomites-Tulitidae Mixed Assemblage}

This assemblage was introduced by Riccardi $e t$ al. (1988a,b, 1990) for the "Cadomites Faunula" defined by Riccardi (1984b) in the Chacay Melehue area. The beds there are about 50 meters thick and are characterized by rather abundant Cadomites of the group C. orbignyi (Gross.) and C. bremeri Tsereteli, preserved in impure sandstone and mudstone. They occur close to Tulites? (Rugiferites?) cf. davaiacensis (Liss.), clearly indicating middle Bathonian. Rare Bullatimorphites (Kheraiceras) cf. bullatus (d'Orb.) and Bomburites cf. microstoma (d'Orb.), which indicate upper Bathonian, occur in an argillaceous matrix and may also have come from this interval or from an even slightly lower one. Such an admixture of faunas of different ages may have been caused by the reworking as olistostromes (turbiditic breccias) of the arenaceous rocks that yielded most or all of the Cadomites, whereas the late Bathonian species came from the autoch thonous shales.

Locally abundant Cadomites bremeri indicate the Bremeri zone at the top of the middle Bathonian in Europe (Westermann and Callomon, 1988). Although closely similar forms appear already in the uppermost Bajocian, the main European-North African distribution of the $C$. bremeri-orbignyi group is in the middle Bathonian. Mangold (1985) has clearly placed the level of Cadomites bremeri at the top of the middle Bathonian. In the Cordillera Domeyko of northern Chile, similar Cadomites occur at a similar level and sometimes even together with Epistrenoceras, indicating the upper Bathonian Retrocostatum zone (A. Hillenbrandt, pers. commun. to GEGW).

At Chacay Melehue, this association is separated from the Megasphaeroceras magnum zone by approximately $\mathbf{1 5 0}$ meters of poorly fossiliferous shales from which middle Bathonian Tulites (Rugiferites?) aff. sofanus (Boehm) was collected. Similar forms occur in the lower Subcontractus zone of Spain - i.e., the Sofanus zone of Sandoval (1983), which also include early Cadomites bremeri. This interval at Chacay Melehue therefore seems to represent part of the upper Bathonian, while containing resedimented earlier Bathonian fauna (Fig. 2).

\section{Steinmanni Standard Zone}

This zone was introduced by Riccardi et al. (1984b) for the "Lilloettia Assemblage Zone" of Riccardi (1984b). It is composed of about 110 meters

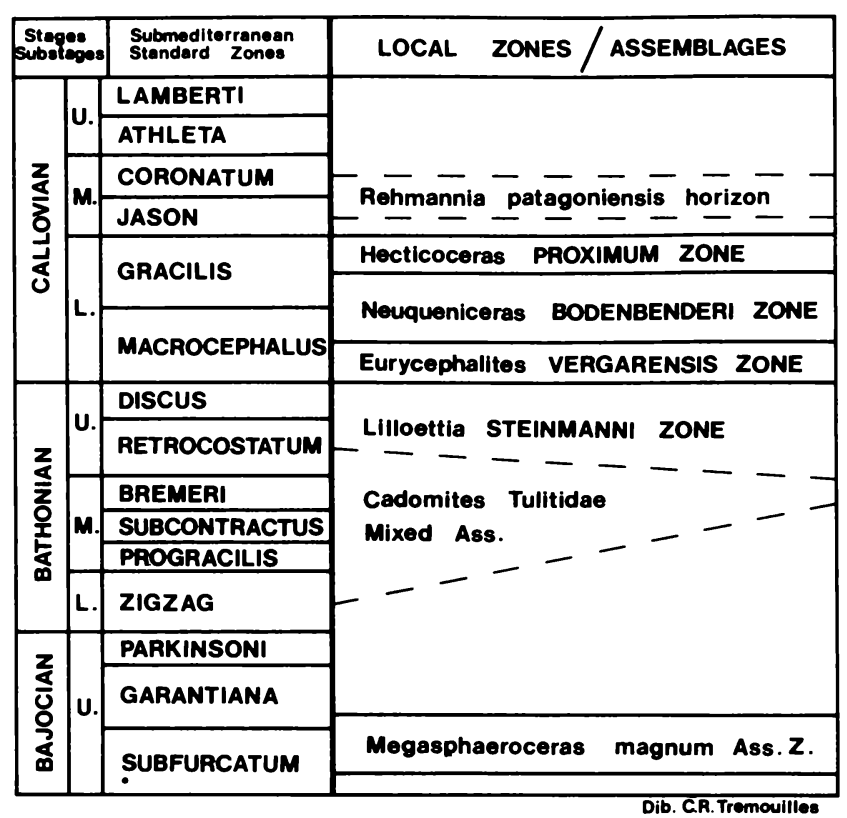

Fig. 2. Correlation of regional ammonite assemblages and zones with the standard chronostratigraphic scale.

of thick shales at Chacay Melehue. The base of the zone was defined where the first Iniskinites occur, below the first appearance of the index species; the top was defined by the base of the overlying Vergarensis zone. The fauna contains Lilloettia steinmanni (Spath) (Fig. 3. no. 3), Iniskinites crassus Ricc. \& West., I. gulisanoi Ricc. \& West., Xenocephalites neuquensis (Stehn), Neuqueniceras (N.) biscissum (Stehn); it is characterized, near the base, by Choffatia aff. aequalis (Roem.) and, in the upper part, by Neuqueniceras (N.) steinmanni Stehn, Choffatia gr. jupiter (Stein.), and C. suborion (Burck.).

In the cemetery section at Caracoles, Chile, this zone consists of at least 17 meters of shales and limestones (base not exposed). The fossiliferous limestone in the middle of this interval yields the index species together with abundant Choffatia jupiter, which marks an easily recognizable horizon in the Cordillera Domeyko. Below L. steinmanni occurs associated with Hecticoceras (Prohecticoceras) blanazense Elmi and Eohecticoceras sp., indicating in the Mediterranean the basal upper Bathonian Blanazense subzone of the Retrocostatum zone. Therefore the age of this zone is late Bathonian - Retrocostatum zone and Discus zone (Fig. 2).

This zone is represented at Arroyo Mulichinco, Arroyo Agua Fria, Sierra de Reyes, and Cerro Puchenque in Argentina, and at Lonquimay and Cordillera Domeyko (Quebrada El Profeta, ?Quebrada San Pedro, Caracoles) in Chile (Fig. 1, loc. 2, 3, 5, 7, $12,20,21)$. At Cualac, Mexico, the Steinmanni standard zone includes at its base Epistrenoceras histricoides (Roll.), marking the Retrocostatum zone in the Mediterranean (Sandoval et al., 1990).

Stehnocephalites gerthi Horizon. This is the "Indocephalites" gerthi assemblage zone or subzone proposed by Riccardi (1984b) and Riccardi et al. 
(1988a,b) (see Riccardi et al., 1990). About 40 meters of shales in the Chacay Melehue section yield an abundant fauna dominated by $S$. gerthi (Spath) in the uppermost part of the Steinmanni zone. Ancillary species belong to the group of Choffatia jupiter (Stein.) and suborion (Burck.) and to Ch. cf. gottschei (Stein.). Stehnocephalites appears to be strictly endemic in the Neuquén Basin and has been found only within about a $100-(250$ ?) $\mathrm{km}$ radius of the type locality at Chacay Melehue - i.e., Arroyo Mulichinco, Arroyo Agua Fria, Sierra de Reyes (La Estrechura, ?Quebrada Remoredo, Agua del Ñaco), and ?Cerro Puchenque (Fig. 1, loc. 2, 3, 5, 7).

Choffatia jupiter Horizon. The interval of the Choffatia jupiter horizon at Caracoles and in the Cordillera Domeyko, northern Chile, may be coeval with the $S$. gerthi horizon of Chacay Melehue bearing similar species of Choffatia. In the Cordillera Domeyko, Epistrenoceras and Hecticoceras (Prohecticoceras) retrocostatum, marking the upper Retrocostatum zone in Europe, have been found mainly below this horizon, but at one locality it also occurs with abundant $C h$. jupiter (Gröschke and Hillebrandt, 1985, p. 153).

Both horizons are probably still latest Bathonian, and the $C h$. jupiter horizon appears to be somewhat diachronous within the upper Retrocostatum and Discus zones.

\section{Vergarensis Standard Zone}

This zone was based on the Eurycephalites vergarensis subzone of the "Eurycephalites Assemblage Zone" of Riccardi (1984b; see Riccardi et al., 1988a,b, 1990); it is about 30 meters thick at Chacay Melehue. This assemblage is characterized by the macroconchiate index species $E$. vergarensis (Burck.) (Fig. 3, no. 2a-b) together with the microconchiate Xenocephalites gottscheri (Tornq.), both of which range throughout the zone, and by late Neuqueniceras steinmanni Stehn and N. (N.) biscissum (Stehn). The last Stehnocephalites, Lilloettia, and Xenocephalites cf. araucanus (Burck.) also occur here.

The index species has also been recorded from Arroyo Mulichinco and ?Arroyo La Bajada in Argentina, and from Valle Vergara, Quebrada Incahuasi, and Quebrada San Pedro in Chile (Fig. 1, loc. 2, 8, 14, $19,21)$. This standard zone has also been recognized at Cualac, Mexico, on the basis of rare Eurycephalites cf. vergarensis (Burck.) (Sandoval et al., 1990).

\section{Bodenbenderi Standard Zone}

This zone was based on the "Eurycephalites rotundus Subzone" of the "Eurycephalites Assemblage Zone" of Riccardi (1984b; see Riccardi et al., 1988a,b, 1990). It is characterized by Neuqueniceras (Frickites) bodenbenderi (Tornq.) (Fig. 4, no. 1a-b), Eurycephalites rotundus (Tornq.) (Fig. 3, no. 4a-b), E. cf. extremus (Tornq.), and the two microconchs Xeno- cephalites stipanicici Ricc. et al. and $X$.? involutus Ricc. \& West. $N$. ( $F$.) cf. antipodum (Gott.) occur in the upper part. In the cemetery section at Caracoles, Chile, this zone is made up of abundant $\mathrm{Neu}$ queniceras (Frickites) bodenbenderi, together with $N$. (F.) antipodum (Gott.), Oxycerites (Alcidellus) obsoletoides Ricc. et al., and Rehmannia (R.) douvillei (Stein.).

The zone has also been recorded at Arroyo Mulichinco, Arroyo Agua Fria, Vega de la Veranada, Sierra de Reyes (La Estrechura, Quebrada Remoredo), Arroyo de la Vaina, Cerro Puchenque, and Arroyo La Bajada in Argentina, and at Cajón Troncoso and Cordillera Domeyko (Quebrada San Pedro) in Chile (Fig. 1, loc. 2, 4-8, 13, 21). The Bodenbenderi standard zone has been recognized in southern Mexico, where the upper part has yielded Rehmannia gr. rehmanni (Oppel), indicating the basal Gracilis zone of the standard sub-Mediterranean zonation (Sandoval et al., 1990).

\section{Proximum Standard Zone}

This zone was introduced by Riccardi et al. (1988a,b, 1990) for the uppermost shales, approximately 60 meters thick, in the Chacay Melehue section. The assemblage is characterized by Hecticoceras (H.) proximum Elmi (Fig. 4, no. 2), $H$. (H.) cf. hecticum (Rein.), H. (H.) cf. boginense (Pet.), H. (Chanasia) navense Roman, and $H$. (Ch.) ardescicum Elmi, as well as by some other poorly known hecticoceratids. This association of Tethyan species can be clearly dated as late Callovian or Gracilis chronozone (Enodatum and Patina subzones, respectively), or latest early Callovian (Fig. 2). The last, rare eurycephalitids, including the large microconch Xenocephalites stipanicici Ricc. et al., are associated with this zone. In the Andes, some reineckeiids pass from the Bodenbenderi zone into this zone, including Neuqueniceras (Frickites) antipodum (Góttsche), Rehmannia (R.) douvillei (Steinmann), and $R$. (R.) cf. paucicostata (Tornq.). Rehmannia (R.) brancoi (Steinmann) and $\boldsymbol{R}$. (R.) stehni (Zeiss) are characteristic of the uppermost part of the zone. Both species probably pass into the lower-middle Callovian boundary. In Europe, Hecticoceras $(H$.) proximum marks the top horizon of the lower Callovian in France (Cariou, 1980). A similar species, Hecticoceras $(H$.) boginense, has been identified for the uppermost part of the Cualac section in Mexico, above the Rehmannia gr. rehman$n i$ association (Sandoval et al., 1990).

\section{Rehmannia (Loczyceras) patagoniensis Horizon}

This horizon is introduced by Riccardi and Westermann $(1991 \mathrm{a}, \mathrm{b})$ on the basis of a 3-meter-thick interval with Rehmannia (Loczyceras) patagoniensis (Weaver) (Fig. 4, no. 3a-b). It appears to be widely distributed in west-central Argentina, from Picún Leufú, Neuquén province, to Sierra de Reyes, Mendoza province (Fig. 1). This horizon appears to yield the youngest Andean reineckeiids. Stratigraphic and 

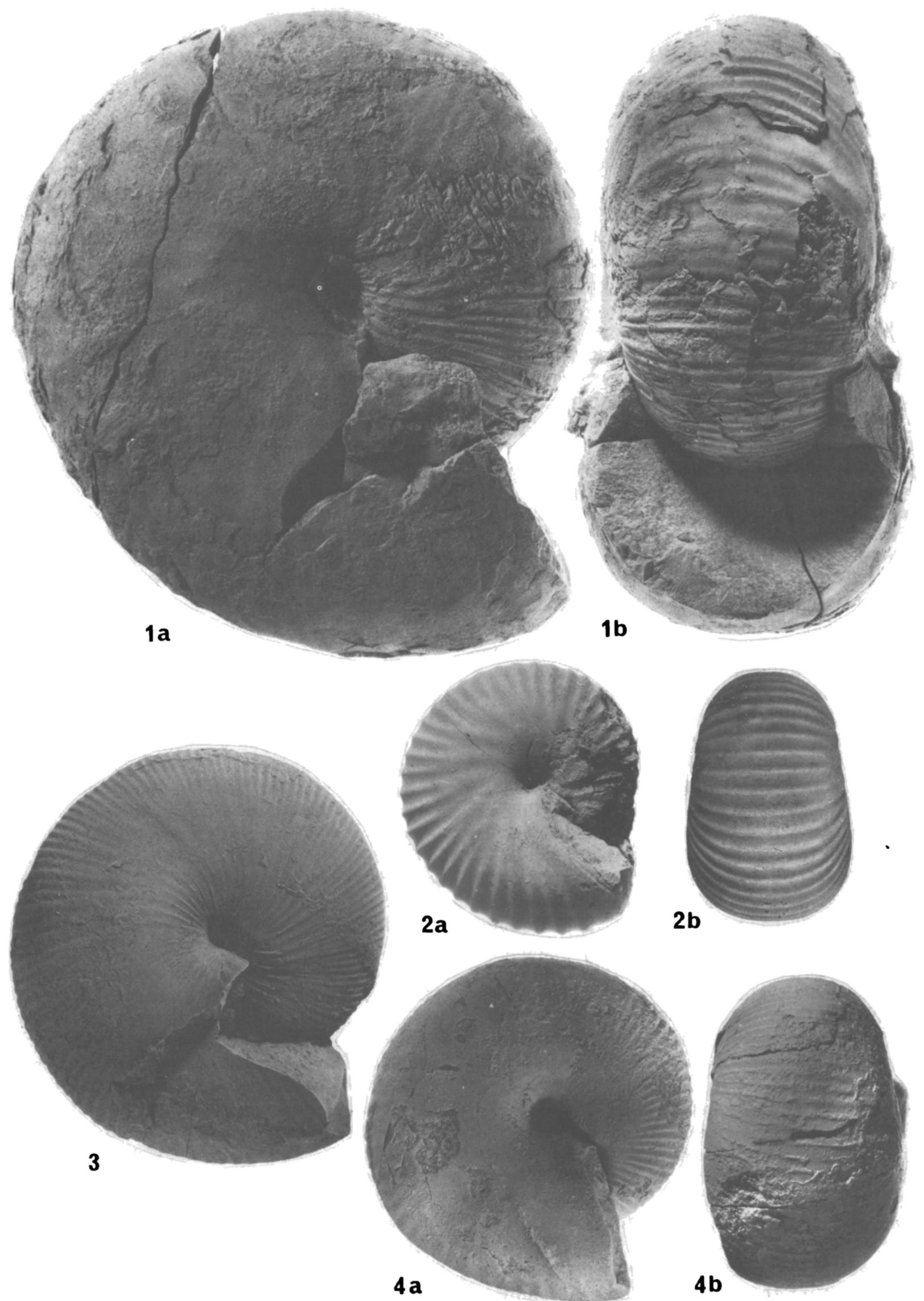

Fig. 3. Numbers 1-3 of the figured fossils are from Chacay Melehue, Argentina; number 4 is from Paso del Espinacito, Argentina. All are in the collections of the Museo La Plata (MLP) or Geologisch-Paläontologisches Institut, Georg August Universitat, Göttingen, Germany (GAUG). All were photographed at $\times 1$, but the illustration has been slightly reduced for publication: $1 a-b$, Megasphaeroceras magnum Riccardi and Westermann (MLP 23931); 2a-b, Eurycephalites vergarensis (Burckhardt) (MLP 12664); 3, Lilloettia steinmanni (Spath) (MLP 12704); 4a-b, Eurycephalites rotundus (Tornquist) (GAUG 496-440). 


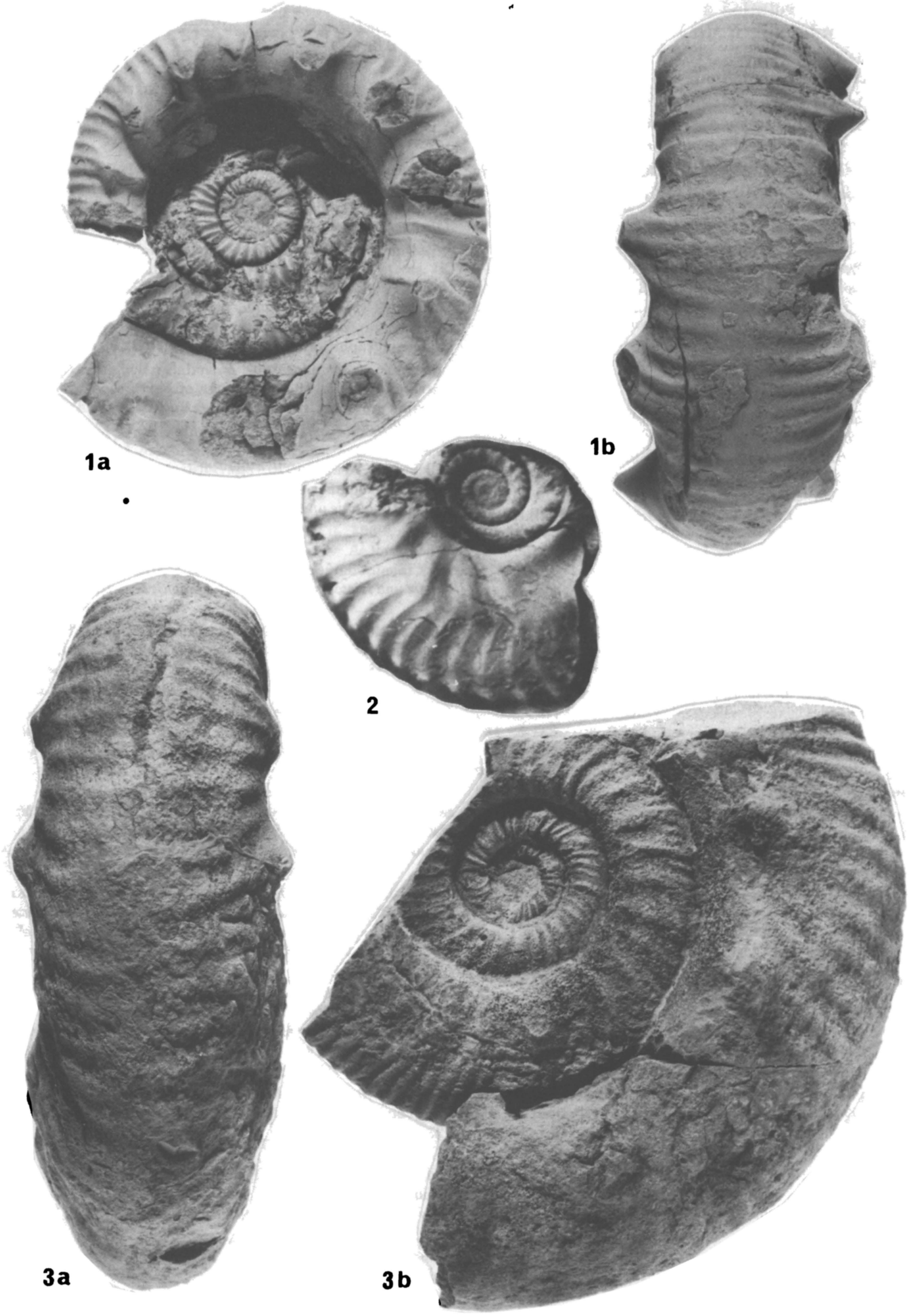

Fig. 4. Numbers 1-2 of the figured fossils are from Chacay Melehue, Argentina; number 3 is from Aguada de la Mula, Sierra de Reyes, Argentina. All are in the collections of the Museo La Plata (MLP). All were photographed at $\times 1$, but the illustration has been slightly reduced for publication: 1a-b, Neuqueniceras (Frickites) bodenbenderi (Tornquist) (MLP 23997); 2, Hecticoceras (H.) proximum Elmi (MLP 12808); 3a-b, Reineckeia (Loczyceras) patagoniensis (Weaver)(MLP 23984). 
paleogeographic evolution indicate that it is younger than levels containing $R$. ( $R$.) brancoi (Steinmann) and $R$. (R.) stehni (Zeiss). The genus Rehmannia is widely distributed throughout the Tethys. The nominal subgenus is present from the upper part of the Macrocephalus zone to the top of the lower Callovian, whereas $R$. (Loczyceras) is present in the Jason to Athleta zones. This and systematic affinities indicate that the horizon is middle Callovian (see Fig. 2).

Acknowledgements-We are indebted to the following for their assistance: C. Cornejo, Universidad de Concepción, Chile; V. Covacevich, J. Davidson, J. Muñoz, and E. Pérez d'A., Servicio de Geología y Minería, Santiago, Chile; G. Chong and L. A. Quinzio, Universidad del Norte, Antofagasta, Chile; A. Jensen, then at Antofagasta, Chile; C. Gulisano, then at Yacimientos Petroliferos Fiscales, Argentina; A. Hillebrandt, Technische Universität Berlin, FRG; R. Vicencio, then at McMaster University, Hamilton, Ontario, Canada; J. C. Vicente, then at Santiago, Chile. We also appreciate the assistance of the acknowledged authors and institutions that helped complete the systematics papers on which this present work is based. This study is a modified and expanded version of a paper that was presented at the Fifth Chilean Geological Congress, and we thank Dr. Harvé for his invitation to submit it to this journal.

\section{REFERENCES}

Bogdanic, T., and Chong, G., 1985. Bioestratigrafia del Jurásico de la zona Preandina Chilena entre los $24^{\circ} 30^{\prime} O 25^{\circ} 30^{\circ}$ de lat. Sur. Actas, IV Congreso Geológico Chileno, Antofagasta 1, 1/38-1/57.

Burckhardt, C., 1900a. Profils géologiques transversaux de la Cordillère Argentino-Chilienne: Stratigraphie et tectonique. Museo La Plata, Sección Geología y Mineralogia, Anales 2, 1-136, lám. 132.

Burckhardt, C., 1900b. Coupe géologique de la Cordillère entre Las Lajas et Curacautin. Museo La Plata, Sección Geología y Mineralogía, Anales 3,1-102, lám. 1-26.

Burckhardt, C., 1903. Beiträge zur Kenntniss der Jura- und Kreideformation der Cordillere. Palaeontographica 50, 1-114, pl. 1-16.

Cariou, E., 1980. L'Étage Callovien dans le Centre-Ouest de la France. Thèse à l'Université de Poitiers, France, Fasc. 1-3, 790 pp.

Cornejo, C., Muñoz, J., and Covacevich, V., 1982. Presencia de Jurásico sedimentario marino en el Cajón Troncoso, Alta Cordillera de los Andes, VII Región, Chile: Notice Preliminar. Actas, III Congreso Geológico Chileno. Concepción, 1, A84-A110.

Damborenea, S. E., 1987. Early Jurassic Bivalvia of Argentina, Part l: Stratigraphical introduction and superfamilies Nuculanacea, Arcacea, Mytilacea and Pinnacea. Palaeontographica A 199 (1-3), 23-111.

Dellapé, D. A., Mombrú, C., Pando, G. A., Riccardi, A. C., Uliana, M. A., and Westermann, G. E. G., 1979. Edad y correlación de la Formación Tábanos en Chacay Melehue y otras localidades de Neuquén y Mendoza. Museo La Plata, Obra Centenario 5, 81-105.

Gottsche, C., 1878. Uber Jurassische Versteinerungen aus der Argentinischen Cordillere. Palaeontographica, Suppl. 3 (2, 3), 1 150, pl. $1-8$.
Groeber, P., 1918. Estratigrafía del Dogger en la República Argentina. Dirección Nacional Geologia y Minas, Buenos Aires, Boletin B18, 5-81.

Groeber, P., Stipanicic, P. N., and Mingramm, A. G., 1953. Jurásico. In: Geografía de la República Argentina. Sociedad Argentina de Estudios Geográficos GAEA, Buenos Aires 2 (1), 143 347.

Gröschke, M., and Hillebrandt, A. von, 1985. Trias und Jura in der mittleren Cordillera Domeyko von Chile $\left(22^{\circ} 30^{\prime}-24^{\circ} 30^{\prime}\right)$. Neues Jahrbuch für Geologie und Paläontologie, Abhandlungen 170, 129166.

Hall, R. L., and Westermann, G. E. G., 1980. Lower Bajocian (Jurassic) Cephalopod Faunas from Western Canada and proposed Assemblage Zones for the Lower Bajocian of North America. Palaeontographica Americana (Ithaca) 9 (52), 93 pp.

Harrington, H. J., 1961. Geology of parts of Antofagasta and Atacama provinces, northern Chile. Bulletin of the American A 8sociation Petroleum Geologists 45 (2), 169-197.

Hillebrandt, A. von, 1970. Zur Biostratigraphie und AmmonitenFauna des südamerikanischen Jura (insbes. Chile). Neues Jahrbuch für Geologie und Paläontologie, Abhandlungen 136, 166-211.

Hillebrandt, A. von, 1977 Ammoniten aus dem Bajocium (Jura) von Chile (Südamerika). Bayerische Staatssammlung für Paläontologie und Historische Geologie (Munich), Mitteilungen 17, 35-69.

Hillebrandt, A. von, and Westermann, G. E. G., 1985. Aalenian (Jurassic) ammonite faunas and zones of the Southern Andes. Zitteliana (Munich) 12,3-55.

Jaworski, E., 1914. Beiträge zur Kenntnis des Jura in SüdAmerika, Teil I: Allgemeiner Teil. Neues Jahrbuch für Mineralogie, Geologie, und Paläontologie 37, 285-342.

Jaworski, E., 1925. Contribución a la paleontología del Jurásico Sudamericano. Publicación de la Dirección General de Mineria, Geologia e Hidrologia, Sección Geología, Buenos Aires 4, 1-160, lám. 1-2.

Keidel, J., 1910. La zona del Mesozoico en la falda oriental de la Cordillera entre el río Diamante y el río Neuquén. Ministerio de Agricultura, Sección Geología, Mineralogía y Minería, Buenos Aires, Anales 5 (2), 57-65.

Leanza, A. F., 1945. Hallazgo de una fáunula Kimmeridgiana en el norte de Neuquén y su significado geológico. Instituto Panamericano de Ingeniería de Minas y Geologí, Buenos Aires, Reunion de Comunicaciones 1, 3-8.

Leanza, A. F., 1946 Las oppelias de Chacay Melehue en el Neuquén. Revista de la Asociación Geológica Argentina 1 (1), 6372.

Leanza, A. F., 1947. Descripción de la fáunula Kimmeridgiana de Neuquén. Dirección Nacional de Geología y Minas, Buenos Aires, Informes Prelımınares y Comunicaciones 1, 3-15, lám. 1-3.

Mangold, C., 1985. Report of the Bathonian working group. International Symposium on Jurassic Stratigraphy, Erlangen 1984, Volume $I$ (edited by O. Michelsen and A. Zeiss), pp. 65-75. Geological Survey of Denmark, Copenhagen, Denmark.

Riccardi, A. C., 1983. The Jurassic of Argentina and Chile. In: Phanerozoic Geology of the World: The Mesozoic, Volume B (edited by M. Moullade and A. E. M. Nairn), pp. 201-263. Elsevier, Amsterdam. 
Riccardi, A. C., 1984a. Los Eurycephalitinae en América del Sur. Actas, III Congreso Argentino de Paleontologia y Bioestratigrafia, Corrientes 151-161.

Riccardi, A. C., 1984b. Las asociaciones de amonitas del Jurásico y Cretácico de la Argentina. Actas, IX Congreso Geológico Argentino, Buenos Aires 4, 569-595.

Riccardi, A. C., 1985. Los Eurycephalitinae Andinos (Ammonitina, Jurásico medio): Modelos evolutivos y resolución paleontológica. Genético Instituto de Fitotecnia, Buenos Aires, Boletín 13, 1-27.

Riccardi, A. C., and Westermann, G. E. G., 1984. Amonitas y estratigrafia del Aaleniano-Bajociano de la Argentina. Actas, IX Congreso Geológico Argentino, Buenos Aires 4, 362-393.

Riccardi, A. C., and Westermann, G. E. G., 1991 a. Middle Jurassic ammonoid fauna and biochronology of the Argentine-Chilean Andes, Part III: Bajocian-Callovian Eurycephalitinae, Stephanocerataceae. Palaeontographica A, 216.1-110.

Riccardi, A. C., and Westermann, G. E. G., 1991b. Middle Jurassic ammonoid fauna and biochronology of the Argentine-Chilean Andes, Part IV: Bathonian-Callovian Reineckeiidae. Palaeontographica $A$, 216. 111-145.

Riccardi, A. C., Westermann, G. E. G., and Elmi, S., 1988a. Zonas de amonites del Bathoniano-Caloviano inferior de los Andes Argentino-Chilenos. Actas, $V$ Congreso Geológico Chileno, Santiago 2, C415-C426.

Riccardi, A. C., Westermann, G. E. G., and Elmi, S., 1988b. The Bathonian-Callovian ammonite zones of the Argentine-Chilean Andes. Proceedings, II International Symposium on Jurassic Stratigraphy, Lisbon 1, 347-358.

Riccardi, A. C., Westermann, G. E. G., and Elmi, S., 1990. The Middle Jurassic Bathonian-Callovian ammonite zones of the Argentine-Chilean Andes. Geobios 22 (5), 553-597.

Rosenfeld, U., and Volkheimer, W., 1980. Turbidite und andere Rhythmite im tieferen Jura des Neuquen Beckens (Argentinien). Neues Jahrbuch für Geologie und Paläontologie, Abhandlungen $159(3), 379-421$.

Sandoval, J., 1983. Bioestratigrafia y Paleontología (Stephanocerataceae y Perisphinctaceae) del Bajociense y Bathoniense en las Cordilleras Béticas. Tésis, Universidad de Granada, España, 613 p., 72 lám.

Sandoval, J., Westermann, G. E. G., and Marshall, M. C., 1990. Ammonite fauna, stratigraphy and ecology of the Bathonian-Callovian (Jurassic) Tecocoyunca Group, South Mexico. Palaeontographica A 210 (4-6), 93-149.
Stehn, E., 1923. Beiträge zur Kenntnis des Bathonian und Callovian in Südamerika. Neues Jahrbuch für Mineralogie, Geologie und Paläontologie 49, 52-158, pl. 1-8.

Steinmann, G., 1881. Zur Kenntnis der Jura- und Kreideformation von Caracoles (Bolivia). Neues Jahrbuch für Mineralogie, Geologie und Paläontologie 1, 239-301, pl. 9-14.

Stipanicic, P. N., 1966. El Jurásico en Vega de la Veranada (Neuquén), el Oxfordense y el diastrofismo Divesiano (Agassiz-Yaila) en Argentina. Revista de la Asociación Geológica Argentina 20, 403478.

Stipanicic, P. N., 1969. El avance en los conocimientos del Jurásico Argentino a partir del Esquema de Groeber. Revista de la Asociación Geológica Argentina 24, 367-388.

Tornquist, A., 1898. Der Dogger am Espinazito Pass. Palaeontologisches Abhandlungen NF 8(2), 135-201, pl. 14-23.

Westermann, G. E. G., 1981. Ammonite biochronology and biogeography of the circum-Pacific Middle Jurassic. Systematics Association, Special Volume 18, 459-498.

Westermann, G. E. G., and Callomon, J. H., 1987. The Macrocephalitidae and associated Bathonian and early Callovian (Jurassic) ammonoids of the Sula Islands and Now Guinea. Palaeontographica A 203 (1-3), 1-90.

Westermann, G. E. G., and Riccardi, A. C., 1972. Middle Jurassic ammonoid fauna and biochronology of the Argentinian-Chilean Andes, Part 1: Hildocerataceae. Palaeontographica A 140,1-116.

Westermann, G. E. G., and Riccardi, A. C., 1979. Middle Jurassic ammonoid fauna and biochronology of the Argentinian-Chilean Andes, Part 2: Bajocian Stephanocerataceae. Palaeontographica A 164, 85-188.

Westermann, G. E. G., and Riccardi, A. C., 1980. The upper Bajocian ammonite Strenoceras in Chile: First circum-Pacific record of the Subfurcatum zone. Newsletters on Stratigraphy 9 (1), 19-29.

Westermann, G. E. G., and Riccardi, A. C., 1985. Middle Jurassic ammonite evolution in the Andean province and emigration to Tethys. Lectures Notes in Earth Sciences (Berlin) 1, 6-34.

Zöllner, W., and Amos, A. J., 1973. Descripción geológica de la hoja 32b, Chos Malal. Servicio Nacional de Minería y Geología, Buenos Aires, Boletin 143, 1-91. 